J. Appl. Glycosci., 56, 1-6 (2009)

(C) 2009 The Japanese Society of Applied Glycoscience

Regular Paper

\title{
Study on a New Preparation of D-Glucose Rich Fractions from Various Lignocelluloses through a Two-step Extraction with Sulfuric Acid
}

(Received September 8, 2008; Accepted October 24, 2008)

\author{
T.A.T.P. Thalagala, ${ }^{1}$ Shotaro Kodama, ${ }^{1}$ Takashi Mishima, ${ }^{1}$ Naoto Isono, ${ }^{1}$ Atsushi Furujyo, ${ }^{2}$ \\ Yuko Kawasaki ${ }^{2}$ and Makoto Hisamatsu ${ }^{1, *}$ \\ 'Laboratory of Food Science and Biotechnology, Department of Sustainable Resource \\ Sciences, Faculty of Bioresources, Mie University \\ (1577, Kurimamachiya-cho, Tsu 514-8507, Japan) \\ ${ }^{2}$ Research and Development Division, Biotechnology Research Section, Biorefinery Group, Oji Paper Co., Ltd. \\ (1-10-6, Shinonome, Koto-ku, Tokyo 135-8558, Japan)
}

\begin{abstract}
Preparing D-glucose with comparatively high yield and purity from many kinds of lignocelluloses through a basically unified method is an important technology because almost all of the yeasts show limitative use of carbon sources in ethanol fermentation. Although cellulase is of great interest in the production of Dglucose, the enzyme degradation demands a pre-treatment for loosening the hard structure of lignocelluloses. A typical acid hydrolysis of lignocelluloses digesting directly to monosaccharides is also used; however, the hydrolysate contains not only a mixture of pentose and hexose but also some chemicals inhibiting the growth of yeast. Therefore, representative samples of hardwood (Japanese oak), softwood (Japanese cedar) and annual plants (sugar cane bagasse) were examined in order to look for a convenient method of collecting oligosaccharides from these biomasses employing the concept that high-molecular-weight molecules with hard structure are gradually loosened and then degraded into low-molecular-weight molecules with strong alkaline or strong acid under mild conditions. Potassium hydroxide was suitable for the annual plant but insufficient for wood in the segregation of hemicellulose and cellulose. Concentrations of sulfuric acid for extracting selectively the majority of hemicelluloses from annual plants and wood were 42.5 and $44 \%$ (v/v), respectively. Lignocellulose $(100 \mathrm{mg})$ was treated with the concentrated sulfuric acid $(10 \mathrm{~mL})$ at $20^{\circ} \mathrm{C}$ for $5 \mathrm{~h}$ under 120 rpm shaking condition. A treatment with $55 \%(v / v)$ sulfuric acid of the residual material under the same conditions was appropriate for preparation of oligosaccharides composed chiefly of D-glucose.
\end{abstract}

Key words: D-glucose, lignocellulose, sulfuric acid, wood, annual plant

From misgivings about global warming, lignocelluloses have been sought for use as renewable sources of energy. Lignocellulosic materials are chiefly composed of cellulose, hemicellulose and lignin. ${ }^{1)}$ For their conversion into fuel ethanol, a method degrading the very hard structure of lignocelluloses is an important strategy and most of the prevailing research is characterized by the process of saccharification. $^{2-4)}$ In the case of low concentrations of acid $(0.5-15 \%)$, biomass was treated at high pressure (10-15 atm) and high temperature $\left(100-250^{\circ} \mathrm{C}\right)$ and also at low temperature $\left(35-45^{\circ} \mathrm{C}\right)$ in the case of a high concentration of acid $(70-80 \%) .^{5-10)}$ Lignocelluloses of softwood, hardwood and annual plants differ in components and conformations from each other; ${ }^{11)}$ however, it is generally thought that ratios of hemicellulose, cellulose and lignin are approximately $3: 4: 3$ for wood and $3: 4: 2$ for annual plants. ${ }^{12,13}$ The remarkable difference among hardwood, softwood and annual plants is observed in the sugar components of hemicelluloses.

From recent environment problems, efficient utilizations of building wastes, agricultural residues such as straw of rice, bagasse of sugar cane and thinnings of trees like Japanese cedar and cypress have been noticed increas-

${ }^{*}$ Corresponding author (Tel. +81-59-231-9614, Fax. +81-59-2319613, E-mail: hisamats@bio.mie-u.ac.jp). ingly. From the point of view concerning the diversity of plant biomass, a uniform method for preparing D-glucose rich fractions from various lignocelluloses might be a useful technology because a large part of yeasts are able to ferment only a few saccharides like D-glucose and sucrose to alcohol. In this study, model lignocelluloses of hardwood, softwood and annual plant residue were examined under various conditions with inorganic matter in order to find a new method of obtaining D-glucose with high purity from the biomass remnants.

\section{MATERIALS AND METHODS}

Lignocellulose materials. Japanese oak (Quercus serrata) as a typical hardwood, Japanese cedar (Cryptomeria japonica) as a typical softwood and sugar cane bagasse (SCB) as a typical annual plant residue obtained from Oji Forest and Product Co., Ltd., Tokyo were used. Their powdery samples with around $8 \%$ moisture content and approximately $500 \mu \mathrm{m}$ chip size were examined. In the case of SCB, the sample $(100 \mathrm{~g})$ suspended in $500 \mathrm{~mL}$ of $75 \%$ (v/v) ethanol was shaken at $120 \mathrm{rpm}$ at $30^{\circ} \mathrm{C}$ overnight in order to eliminate sucrose remaining in the bagasse. The sucrose-free SCB (SCB-s) was filtered and then lyophilized. The amount of sucrose in SCB was approximately $20 \%(\mathrm{w} / \mathrm{w})$. 
Alkaline treatment of lignocellulose in various concentrations. In a Teflon tube $(50 \mathrm{~mL}), 100 \mathrm{mg}$ of lignocellulose was suspended in $10 \mathrm{~mL}$ of potassium hydroxide solution of various concentrations from $10-30 \%(\mathrm{w} / \mathrm{v})$ and shaken at $120 \mathrm{rpm}$ at $30^{\circ} \mathrm{C}$ for $72 \mathrm{~h}$. The tube was chilled in an ice bath to stop the reaction and then centrifuged at $6000 \mathrm{rpm}$ at $0^{\circ} \mathrm{C}$ for $30 \mathrm{~min}$. One $\mathrm{mL}$ of the each supernatant was neutralized with $10 \%(\mathrm{v} / \mathrm{v})$ sulfuric acid and then the amounts of total sugar (TS) estimated by phenol sulfuric acid method ${ }^{14)}$ and the reducing strength of sugar (RS) by the modified Park-Johnson method. ${ }^{15}$ The values of average degree of polymerization (DP) were estimated by dividing the value of TS by that of RS.

Acid treatment of lignocellulose in various concentrations. In a Teflon tube $(50 \mathrm{~mL}), 100 \mathrm{mg}$ of lignocellulose was suspended in $10 \mathrm{~mL}$ of sulfuric acid solution of various concentrations from $10-60 \%(\mathrm{v} / \mathrm{v})$ and shaken at $120 \mathrm{rpm}$ for $5 \mathrm{~h}$. A series of tests was conducted both at 20 and $30^{\circ} \mathrm{C}$. The tube was chilled in an ice bath to stop the reaction. The samples treated with acid concentrations higher than $45 \%(\mathrm{v} / \mathrm{v})$ were mixed with $10 \mathrm{~mL}$ of water because of the gelatinous liquid. All samples were centrifuged at $6000 \mathrm{rpm}$ at $0^{\circ} \mathrm{C}$ for $30 \mathrm{~min}$. One $\mathrm{mL}$ of the each supernatant was neutralized with $2 \mathrm{~N}$ sodium hydroxide and the amounts of TS and RS were estimated and DP values were calculated.

Analysis. The neutral sugars of D-glucose, D-xylose, D-mannose, L-arabinose and D-galactose were analyzed by GC/Mass chromatography (GCMS-QP2010, Shimadzu Corporation, Kyoto, Japan). Derivatives of alditol acetates were prepared as described by Blakeney et al. ${ }^{16}$ Chromatographic separation was performed with a $30 \mathrm{~m} \times 0.25 \mathrm{~mm}$ $\mathrm{SP}^{\mathrm{TM}} 2380$ fused SILICA capillary column operating with $1 \mathrm{~mL} / \mathrm{min}$ helium as the carrier gas. The temperature was kept at $210^{\circ} \mathrm{C}$ for $3 \mathrm{~min}$ and heated up to $240^{\circ} \mathrm{C}$ within 2 min, at an increasing rate of $15^{\circ} \mathrm{C} / \mathrm{min}$ and that continued for $7 \mathrm{~min}$ to complete the total analysis time of $12 \mathrm{~min}$.

\section{RESULTS AND DISCUSSION}

\section{Characteristics of saccharides obtained by alkaline treatment.}

As the ratio of hemicellulose and cellulose in lignocelluloses is generally $3: 4$, the amount of hemicellulose and that of cellulose could be estimated roughly as 30 and 40 $\mathrm{mg}$, respectively, in $100 \mathrm{mg}$ of sample. As shown in Fig. 1A, the TS amounts of SCB-s (annual plant residue) showed around $35-38 \%(\mathrm{w} / \mathrm{w})$ in all potassium hydroxide solutions tested and it could be thought that almost all hemicellulose was extracted. The average DP showed values of around 8-11 (Fig. 1B). On the other hand, the TS amounts for Japanese oak (hardwood) and Japanese cedar (softwood) were $17-20 \%(\mathrm{w} / \mathrm{w})$ and $16^{-18 \%}(\mathrm{w} / \mathrm{w})$ in all potassium hydroxide solutions tested, respectively (Fig. 1A). It could be suggested that even strong alkaline treatment could not extract hemicelluloses sufficiently in the case of wood. Even longer treatment for one week at $30^{\circ} \mathrm{C}$ and stronger treatment at the high temperature of 70 ${ }^{\circ} \mathrm{C}$ did not remarkably increase the TS amount (data not shown). The average DP showed comparatively large values of around 14-16 (Fig. 1B). The results suggested that
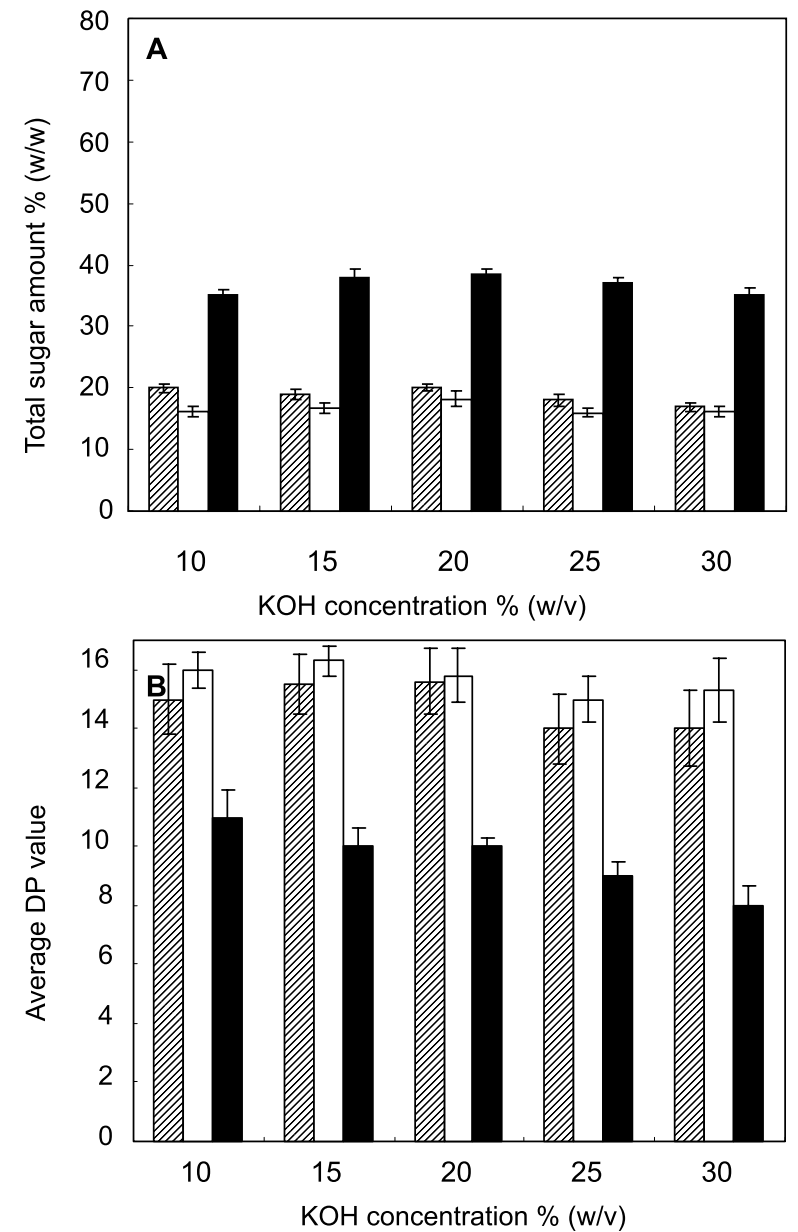

Fig. 1. Total sugar amount $\%(w / w)(A)$ and average DP value (B) of saccharides extracted from lignocelluloses treated with various concentrations of potassium hydroxide.

Lignocelluloses $100 \mathrm{mg}$ each of Japanese oak ( cedar $(\square)$ and SCB-s ( $\square$ ) were treated with $10-30 \%(\mathrm{w} / \mathrm{v})$ potassium hydroxide $(10 \mathrm{~mL})$ at $30^{\circ} \mathrm{C}$ for $72 \mathrm{~h}$ under $120 \mathrm{rpm}$ shaking condition (Data are average of two separate experiments).

the treatment of strong alkaline might be segregate hemicellulose and cellulose for annual plant residues but was inadequate for woods.

\section{Characteristics of saccharides obtained by acid treat- ment.}

As shown in Figs. 2A and 3A, the TS amounts showed unique rising patterns with the first increase at 30.0$42.5 \%(\mathrm{v} / \mathrm{v})$ sulfuric acid concentrations and the second increase at $45.0-55.0 \%(\mathrm{v} / \mathrm{v})$ sulfuric acid concentrations and it could be thought that there were two kinds of extracted materials. Up to around $42.5 \%$ (v/v) sulfuric acid, it could be suggested that lots of chemical linkages of hemicellulose were broken preferentially and those of cellulose were substantially kept. At the second sharp increase of TS amount, crystalline lattices of cellulose were disrupted and converted into a completely amorphous state forming a gelatinous substance. ${ }^{17)}$ It could be thought that cellulose was extremely susceptible to hydrolysis of sulfuric acid at concentrations higher than $60.0 \%(\mathrm{v} / \mathrm{v})$.

Regarding the treatment at $20^{\circ} \mathrm{C}$, the TS amount of SCB-s was $38 \%(\mathrm{w} / \mathrm{w})$ on the treatment of $42.5 \%(\mathrm{v} / \mathrm{v})$ sulfuric acid; it could be suggest that almost all hemicellulose was extracted from SCB-s. On the other hand, the 

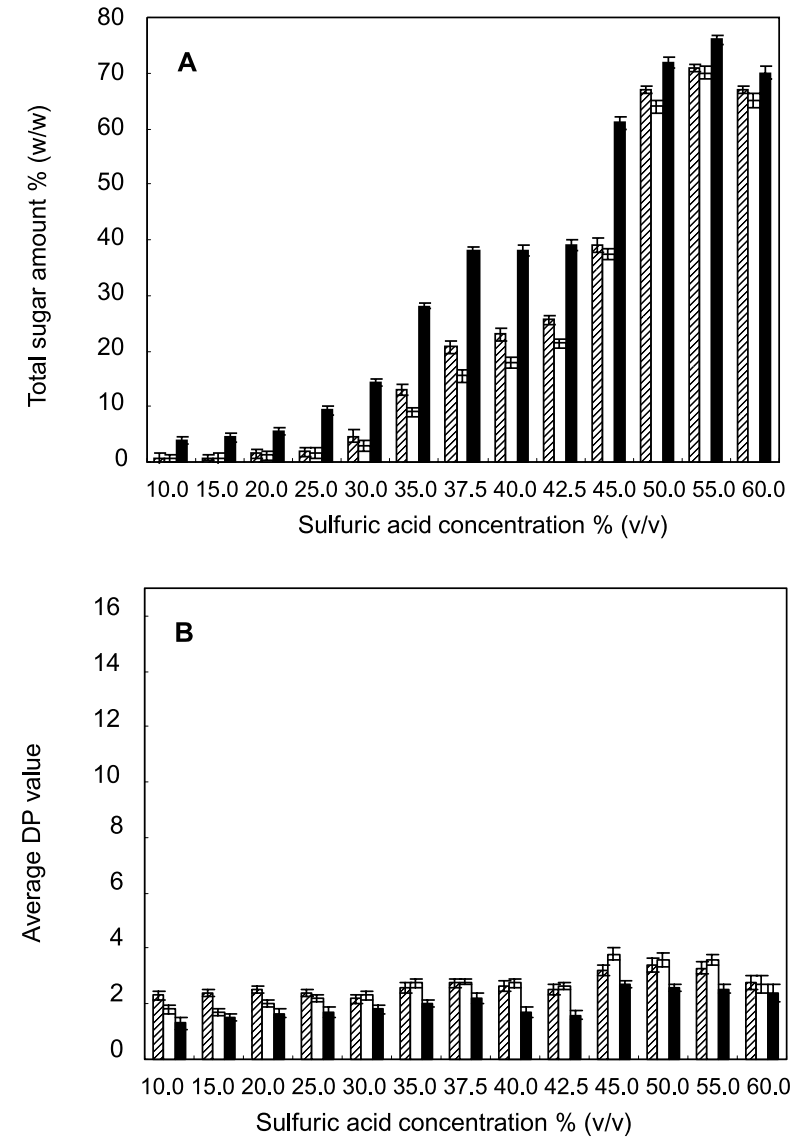

Fig. 2. Total sugar amount $\%(w / w)(A)$ and average $D P$ value (B) of saccharides extracted from lignocelluloses treated with various concentrations of sulfuric acid at $20^{\circ} \mathrm{C}$.

Lignocelluloses $100 \mathrm{mg}$ each of Japanese oak (UTात), Japanese cedar $(\square)$ and SCB-s ( $\square$ ) were treated with 10-60\% (w/v) sulfuric acid $(10 \mathrm{~mL})$ at $20^{\circ} \mathrm{C}$ for $5 \mathrm{~h}$ under $120 \mathrm{rpm}$ shaking condition (Data are average of two separate experiments).

TS amount for woods was around $22-25 \%(\mathrm{w} / \mathrm{w})$ on the treatment of $42.5 \%(\mathrm{v} / \mathrm{v})$ sulfuric acid and that of $45.0 \%$ $(\mathrm{v} / \mathrm{v})$ sulfuric acid was around $37.5-39.0 \% \quad(\mathrm{w} / \mathrm{w})$ (Fig. 2A). For the extraction of saccharides derived from hemicelluloses of woody biomass, it could be suggest that $44.0 \%(\mathrm{v} / \mathrm{v})$ sulfuric acid was suitable to achieve the expected TS amount of $30 \%(\mathrm{w} / \mathrm{w})$ according to the general ratio of sugar composition. These suggestions could be confirmed from the data of their sugar components described later (see Table 2).

TS amounts for $55 \%(\mathrm{v} / \mathrm{v})$ sulfuric acid at $20^{\circ} \mathrm{C}$ showed the highest values of 71,70 and $76 \%$ (w/w) for Japanese oak, Japanese cedar and SCB-s, respectively (Fig. 2A). It could be recognized that these values were very similar to total amounts of saccharides derived from both hemicellulose and cellulose. ${ }^{18)}$ The average DP values of saccharides obtained under the condition at $20^{\circ} \mathrm{C}$ were 1.5-2.7 for SCB-s and 1.7-3.8 for woods (Fig. 2B), and those of saccharides obtained under the condition at $30^{\circ} \mathrm{C}$ were 1.0-1.8 for SCB-s and 1.1-2.9 for woods (Fig. 3B). TS amounts on the treatment of $55 \%(\mathrm{v} / \mathrm{v})$ sulfuric acid at $30^{\circ} \mathrm{C}$ fell slightly to 66,68 and $73 \%(\mathrm{w} / \mathrm{w})$ for Japanese oak, Japanese cedar and SCB-s, respectively (Fig. 3A), suggesting over-decomposition of hemicellulosic sugars. The treatment of $50 \%(\mathrm{v} / \mathrm{v})$ sulfuric acid at $30^{\circ} \mathrm{C}$ did not show so high TS amounts as $55 \%(\mathrm{v} / \mathrm{v})$ sul-
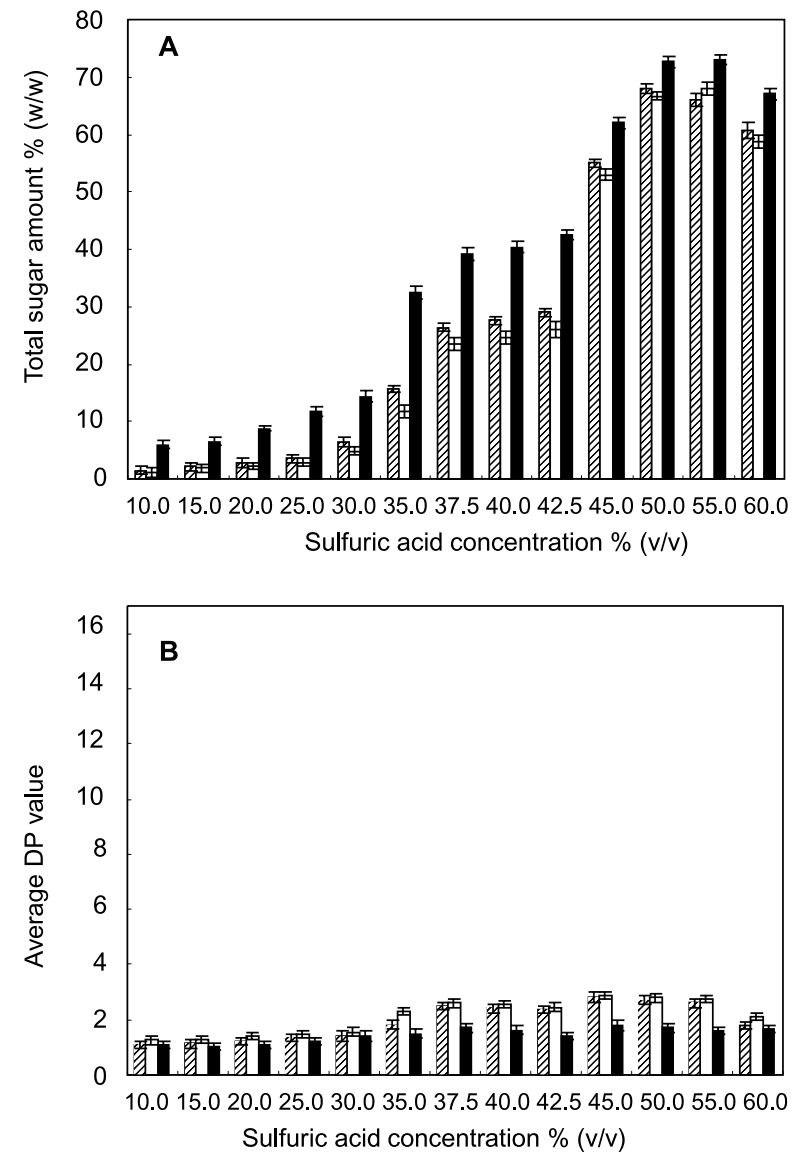

Fig. 3. Total sugar amount $\%(w / w)(A)$ and average $D P$ value (B) of saccharides extracted from lignocelluloses treated with various concentrations of sulfuric acid.

Lignocelluloses $100 \mathrm{mg}$ each of Japanese oak (WIIA), Japanese cedar $(\square)$ and SCB-s ( $)$ were treated with $10-60 \%(\mathrm{w} / \mathrm{v})$ sulfuric acid $(10 \mathrm{~mL})$ at $30^{\circ} \mathrm{C}$ for $5 \mathrm{~h}$ under $120 \mathrm{rpm}$ shaking condition (Data are average of two separate experiments).

furic acid at $20^{\circ} \mathrm{C}$. So, it could be thought that the $55 \%$ (v/v) sulfuric acid is an appropriate concentration for cellulose extraction under the treatment at $20^{\circ} \mathrm{C}$ for $5 \mathrm{~h}$.

\section{Tentative test of the two-step extraction.}

As the first step, SCB-s (100 mg) was suspended in $42.5 \%(\mathrm{v} / \mathrm{v})$ sulfuric acid $(10 \mathrm{~mL})$, and $100 \mathrm{mg}$ each of hard and soft woods was also done in $44 \%$ (v/v) sulfuric acid $(10 \mathrm{~mL})$. The reaction mixtures were subjected to $120 \mathrm{rpm}$ shaking condition at $20^{\circ} \mathrm{C}$ for $5 \mathrm{~h}$ and then centrifuged at $6000 \mathrm{rpm}$ at $0^{\circ} \mathrm{C}$ for $30 \mathrm{~min}$. TS amounts of the supernatants of Japanese oak, Japanese cedar and SCB-s were 28.0, 29.0 and $37.0 \%(\mathrm{w} / \mathrm{w})$, respectively and their average DP values were 2.7, 3.1 and 2.0, respectively (Table 1).

As the second step, the precipitates were re-suspended in $55 \%(\mathrm{v} / \mathrm{v})$ sulfuric acid $(10 \mathrm{~mL})$ and subjected to $120 \mathrm{rpm}$ shaking condition at $20^{\circ} \mathrm{C}$ for $5 \mathrm{~h}$. Reaction mixtures were mixed with water $(10 \mathrm{~mL})$ under chilled condition and then centrifuged at $6000 \mathrm{rpm}$ at $0^{\circ} \mathrm{C}$ for $30 \mathrm{~min}$. TS amounts of the resulted supernatants were 46.2, 44.6 and $40.0 \%(\mathrm{w} / \mathrm{w})$, for Japanese oak, Japanese cedar and SCB-s respectively and their average DP values were 3.2, 3.5 and 2.7, respectively (Table 1). Sugar components of each extraction were analyzed for further verification. 
Table 1. Total sugar (TS) amounts and average DP values of oligosaccharides derived from hemicellulose and cellulose obtained by the two-step extraction with sulfuric acid and suitable condition for preparation of their monosaccharides.

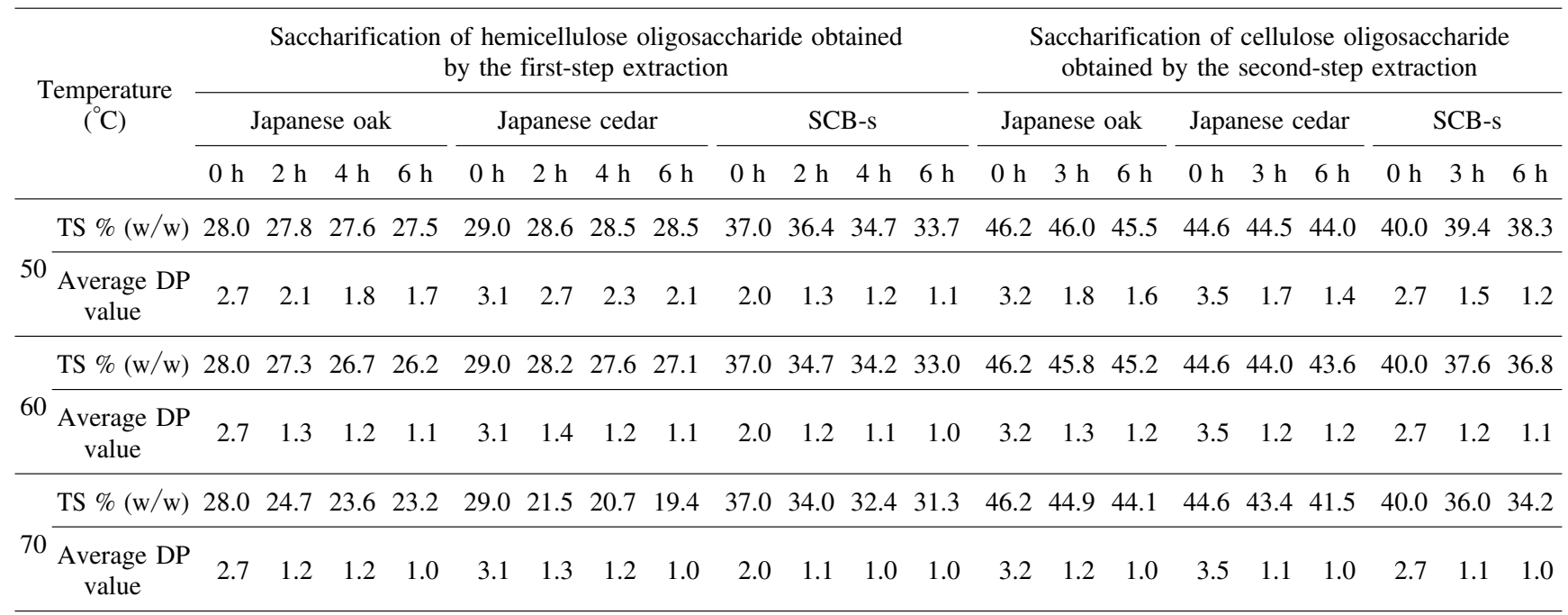

Table 2. Properties of hemicellulosic and cellulosic oligosaccharides obtained by the two-step extraction with sulfuric acid from lignocelluloses of Japanese oak, Japanese cedar and SCB-s.

\begin{tabular}{|c|c|c|c|c|c|c|}
\hline \multirow{2}{*}{$\begin{array}{c}\text { Neutral sugar } \\
(\%)\end{array}$} & \multicolumn{3}{|c|}{ Hemicellulosic oligosaccharide (first-step extraction) } & \multicolumn{3}{|c|}{ Cellulosic oligosaccharide (second-step extraction) } \\
\hline & Japanese oak & Japanese cedar & SCB-s & Japanese oak & Japanese cedar & SCB-s \\
\hline L-Arabinose & 2.2 & 8.4 & 6.3 & ND & ND & 0.3 \\
\hline D-Xylose & 67.4 & 37.3 & 84.6 & 2.5 & 3.5 & 4.3 \\
\hline D-Mannose & 0.5 & 29.0 & 2.0 & ND & 3.7 & ND \\
\hline D-Galactose & 8.3 & 5.5 & ND & ND & ND & ND \\
\hline D-Glucose & 21.6 & 19.8 & 7.1 & 97.5 & 92.8 & 95.4 \\
\hline
\end{tabular}

ND, Not detected.

\section{Determination of appropriate saccharification condi- tion of the oligosaccharide.}

The obtained supernatant $(5 \mathrm{~mL})$ of the first-step extraction (oligosaccharides of hemicellulose) was mixed with $2.5 \mathrm{~mL}$ of water gradually to drop the acid concentration for the following saccharification. The obtained supernatants $(10 \mathrm{~mL})$ of the second-step extraction (oligosaccharides of cellulose) were also used for the saccharification. The solutions were saccharified under various conditions combining reaction temperatures from $50^{\circ} \mathrm{C}$ to $70^{\circ}$ $\mathrm{C}$ and reaction times from $2 \mathrm{~h}$ to $6 \mathrm{~h}$ by shaking at 120 $\mathrm{rpm}$ in a water bath. Appropriate saccharification conditions were chosen considering synthetically both the average DP values and TS amount (Table 1). They were decided to be at $60^{\circ} \mathrm{C}$ for $2 \mathrm{~h}$ for oligosaccharides of hemicellulose and at $60^{\circ} \mathrm{C}$ for $6 \mathrm{~h}$ for those of cellulose.

\section{Sugar components of oligosaccharides obtained by the two-step extraction.}

From data for the first step extraction in Table 2, it was found that oligosaccharides of Japanese oak (hardwood) and SCB-s (annual plant) were mainly composed of Dxylose and that of Japanese cedar (softwood) composed of D-xylose, D-mannose and D-glucose. The principal component of hemicellulose in hardwoods and annual plants is glucuronoxylan and that of softwoods is glucomannan. ${ }^{19)}$ A higher amount of arabinose was observed both in Japanese cedar and SCB-s compared to the Japanese oak. Hemicelluloses of softwood and annual plants differ from that of hardwood in the occurrence of arabinofuranose units linked $\alpha-(1 \rightarrow 3)$ to the xylan backbone. ${ }^{19)}$ SCB-s showed minor amounts of $\mathrm{D}$-galactose and $\mathrm{D}$-mannose. ${ }^{20)}$ These results showed that the oligosaccharides of firststep extraction were derived mainly from their hemicellulose portions. In fact, minor amount of glucose from amorphous cellulose may be incorporate with this fraction.

From data for the second step extraction shown in Table 2, oligosaccharides of Japanese oak, Japanese cedar and SCB-s were mainly composed of D-glucose (>90\%), supporting the assumption that they were oligosaccharides derived mainly from cellulose portions. These results suggested that the two-step extraction of biomass could be used to obtain two kinds of oligosaccharides derived mainly from hemicellulose and cellulose.

There are two famous technologies for degradation of lignocellulose with sulfuric acid. One method with dilute sulfuric acid is based on a treatment using high temperature and high pressure and degrades mainly hemicelluloses. Some hemicellulosic sugars are fermented to bio ethanol and the residual cellulose is further digested with enzymes for subsequent ethanol fermentation. ${ }^{21)}$ Another method with concentrated sulfuric acid is based on a treatment using 70-80\% sulfuric acid at low temperature (35$45^{\circ} \mathrm{C}$ ) and degrades both hemicellulose and cellulose. ${ }^{22)}$ So, a mixture of pentoses and hexoses is obtained. As hardly any yeasts can use D-xylose for ethanol fermentation, it is more desirable to take measures against Dglucose. The method in this paper is close into part both methods described above. The concentrations of sulfuric 
acid, treatment condition and temperature are similar to those of the concentrated sulfuric-acid method and the separation of component sugars from hemicellulose and cellulose is similar to the dilute sulfuric-acid method. It could be estimated that almost all lignin might be left in the residue from the residual color and yields of sugars. From these comparisons, this method has one merit in the separated preparation of component sugars relating hemicellulose and cellulose and another merit of using low temperature and atmospheric pressure.

As provision for the problem of global worming, ethanol fermentation from agricultural residues such as straw of rice and bagasse of sugar cane, thinnings of Japanese cedar and cypress have attracted interest. From the point of view of efficient utilization of remnants of various biomasses, a uniform method for preparing D-glucose might be a useful technology. So, it could be proposed that $43.5 \%(\mathrm{v} / \mathrm{v})$ sulfuric acid for the first extraction and $55.0 \%(\mathrm{v} / \mathrm{v})$ sulfuric acid for the second extraction is appropriate for the treatment of all biomass hardwood, softwood and annual plants. The residual acid after the acid treatment and saccharification is removed by ion exchange chromatography to obtain sugars comprising mainly Dglucose for ethanol fermentation as described in our next paper. $^{23)}$

\section{REFERENCES}

1 ) M. Rowell and R. Pettersen: Cell wall chemistry. in Hand Book of Wood Chemistry and Wood Composites, S. James, S. Jeffery, A. Tshabalala Mandla, eds., CRC Press, New York, pp. 30-70 (2005).

2 ) K. Ohgren, J. Vehmaanpera, M. Siika-Aho, M. Galbe, L. Viikari and G. Zacchi: High temperature enzymatic pre-hydrolysis prior to simultaneous saccharification and fermentation of steam pretreated corn stover for ethanol production. Enzyme Microb. Technol., 40, 607-613 (2007).

3 ) M. Linde, M. Galbe and G. Zacchi: Simultaneous saccharification and fermentation of steam pretreated barley straw at low enzyme loading and low yeast concentration. Enzyme Microb. Technol., 40, 1100-1107 (2007).

4 ) Y. Shen, Y. Zhang, T. Ma, X. Bao, F. Du, G. Zhuang and Y. $\mathrm{Qu}$ : Simultaneous saccharification and fermentation of acid treated corn cobs with a recombinant Saccharomyces cerevisiea expressing $\beta$-glucosidase. Bioresour. Technol., 99, 5099-5103 (2008).

5 ) X.F. Sun, F. Xu, R.C. Sun, Y.X. Wang, P. Fowler and M.S. Baird: Characteristics of degraded lignin obtained from steam exploded wheat straw. Polym. Degrad. Stab., 86, 245-256 (2004).

6 ) M. Ballesteros, J.M. Oliva, M.J. Negro, P. Manzananes and I. Ballesteros: Ethanol from lignocellulose materials by simultaneous saccharification and fermentation process (SFS) with Kluyueromyces marxiannus CECT 10875. Process Biochem., 41, 1843-1848 (2004).

7 ) J. Soderstrom, L. Pilcher, M. Galbe and G. Zacchi: Two-step steam pre-treatment of softwood by dilute sulfuric impregnation for ethanol production. J. Biomass Bio Energy, 24, 475486 (2003).

8 ) J. Mohammad and T. Keikhosro: Acid based hydrolysis process for ethanol from lignocellulosic materials. J. Bioresour., 2, 472-499 (2007)

9 ) R. Ic, M. Si and R. Rclb: Dilute acid hydrolysis for optimization of xylose recovery from rice straw in a semi pilot reactor. Ind. Crop Prod., 7, 171-176 (2003).

10) A. Graf and T. Koehler: Appendix B: Overview of celluloseethanol production technology. in An Evaluation of Potential for Bio Ethanol Production in Oregon Using Cellulose Based Feedstock, A. Graf, eds., Academic Press, New York, pp. 5760 (2000).

11) R.C. Pittersen: The chemical composition of wood. in The Chemistry of Solid Wood, R.M. Roger, eds., American Chemical Society, Washington, pp. 58-75 (1984).

12) K. Miyamoto, Y. Ado, Y. Asada, J.R. Benemann, M. Kishimoto, J. Miyake and N. Nishio: Renewable biological systems for alternative sustainable energy production. in FAO Agriculture Service Bulletins 12, United Nations, New York, pp. 1530 (1997).

13) W.R. Hutter: Non-wood plant fiber characteristics. in Utilization of Annual Plants and Agricultural Residues for the Production of Pulp and Paper, Non Wood Plant Fiber Pulping Progress Report \#19, TAPPI Press, Atlanta, pp. 49-70 (1997).

14) M. Dubois, K.A. Gilles, J.K. Hamilton, P.A. Rebers and F. Smith: Colorimetric method for determination of sugars and related substances. Carbohydr. Res., 28, 350-356 (1956).

15) Y. Takeda, H.P. Guan and J. Preiss: Branching of amylose by the branching isoenzymes of maize endosperm. Carbohydr. Res., 240, 253-263 (1993).

16) A.B. Blakeney, P.J. Harris, R.J. Henry and B.A. Stone: A simple and rapid preparation of aldetol acetates from monosaccharide analysis. Carbohydr. Res., 113, 291-299 (1983).

17) W.A. Farone and J.E. Cuzens: Method of producing sugars using strong acid hydrolysis. U.S. Patent No. 5726046, California, pp. 1-15 (1998).

18) R.M. Rowell: Composite materials from agricultural resources. in Research in Industrial Application of Non Food Crops, 1: Plant Fibers, O. Ole, R. Finn and L. Jorgen, eds., Academy of Technical Science, Lundtoftevej, pp. 27-41 (1995).

19) T.S. Jefries: Biodegradation of lignin and hemicelluloses. in Biochemistry of Microbial Degradation, C. Ratledge ed., Kluwer Academic Publishers, London, pp. 233-251 (1994).

20) J.S. Han and J.S. Rowell: Chemical composition of fibers. in Paper and Composites from Agrobased Resources, M. Roger, R.A. Raymond and Y.K. Judith, eds., Academic Press, New York, pp. 83-134 (1997).

21) W.J. Jr. Frederick, S.J. Lien, C.E. Courchene, N.A. DeMartini, A.J. Ragauskas and K. Lisa: Production of ethanol from carbohydrates from loblolly pine: A technical and economic assessment. Bioresour. Technol., 99, 5051-5057 (2008).

22) J. Iranmahboob, F. Nadim and S. Monemi: Optimizing acid hydrolysis; a critical step for production of ethanol from mixed wood chips. J. Biomass Bioenergy, 22, 401-404 (2002).

23) T.A.T.P. Thalagala, S. Kodama, T. Mishima, N. Isono, A. Furujyo, Y. Kawasaki and M. Hisamatsu: Study on ethanol fermentation using D-glucose rich fraction obtained from lignocelluloses by a two-step extraction with sulfuric acid and $I s$ satchenkia orientalis MF 121. J. Appl. Glycosci., 56, 7-11 (2009) 
リグノセルロースの硫酸 2 段階抽出から純度の

高いグルコース画分を得る新しい調製法の研究

T.A.T.P. タラガラ', 児玉祥太郎 ${ }^{1}$, 三島 隆', 磯野直人 ${ }^{1}$, 古城 敦 ${ }^{2}$, 川崎優子 ${ }^{2}$, 久松 臭 $^{1}$ ${ }^{1}$ 三重大学大学院生物資源学研究科食品資源工学研究室

(514-8507 津市栗真町屋町 1577)

2 王子製紙株式会社研究開発本部総合研究所

バイオ関連研究セクション

(135-8558 東京都江東区東雲 1-10-6)

酵母がエタノール発酵できる糖は限られているため, 基本的に統一された方法により, 多くのリグノセルロー スから純度が高く収率もよいグルコースを調製する技術 は重要である。セルラーゼはグルコース生産において注 目されているが, 酵素分解には硬質なリグノセルロース を柔らかくする前処理が必要である。酸加水分解で単糖 にまで分解する方法もあるが, リグノセルロースは 5 単 糖と 6 単糖の混合物であることのほかに, 酵母生育阻害 物質も含んでいる。そこで, 広葉樹 (コナラ), 針葉樹 (スギ), 一年草 (バガス) をモデル試料とし，マイルドな 条件下で強アルカリや強酸を使用し, 硬質な高分子を緩 やかにほぐして低分子化するという考えに基づき，これ らのバイオマスからオリゴ糖を調製する方法を見つける ことを目的として研究を行った. その結果, へミセル ロースとセルロースを分けるためには，アルカリ処理は 一年草には適用できたが木材には不十分であった。それ に対し硫酸処理は，一年草には $42.5 \%$ 硫酸が，木材には 44\% 硫酸がへミセルロース系オリゴ糖を抽出するのに優 れていた．さらにこの処理の残渣を $55 \%$ 硫酸で処理する とセルロース系オリゴ糖が抽出された。抽出されたそれ ぞれのオリゴ糖の糖組成分析から, 前段処理で得られた オリゴ糖はへミセルロース関連の単糖であること, 単糖 の種類も広葉樹, 針葉樹, 一年草の特長が出ていること, 後段処理からは $90 \%$ 以上の純度があるグルコースが得ら れたことからセルロース系オリゴ糖であることが確認で きた。 